\title{
ANALYSIS OF HONEST POLITICAL CONSTRUCTION IN MULTINATIONAL ENTERPRISES FROM THE PERSPECTIVE OF BUSINESS ANTHROPOLOGY
}

\author{
XIAONA WANG \\ DALIAN MARITIME UNIVERSITY
}

\begin{abstract}
Using the research approaches in business anthropology, this article aims to explore and analyze incorruptible construction in multinational enterprises in order to facilitate transnational corporations' culture consultations and reinforce incorruptible construction policies. By analyzing the multinational enterprises' actions under China's "Going Out" policy, as well as studying the relevant materials at home and abroad, the author draws the conclusion that business corruption appears to be positively correlated with social corruption, or even government corruption, and theoretically proposes preliminary solutions for the culture consultation in multinational enterprises. The solutions include establishing a capable enterprise cultural construction institution and carrying on cultural choice through analyzing the inner cultural differences in an enterprise. Finally, a corporate culture which has its own characteristics can be constructed. This is a practice of anti-corruption spirit to reduce the resistance against honest political construction in multinational enterprises.
\end{abstract}

Keywords: business anthropology, multinational enterprise, corruption, culture consultation

\section{Introduction}

From the perspective of anthropology, interdisciplinary and multi-view research not only becomes a way for dialogue between anthropology and other subjects, but also becomes a new horizon where the other subjects contribute to the diversified and cross-domain development of anthropology. 
Many of the problems confronted by the business world can be solved applying the theory and methods of anthropology. If multinational corporations want to survive and develop in various cultural environments, then on the one hand, they should value the composite state of physical resources between the two countries, and on the other, two kinds of enterprise cultural resources should be fused; and anthropologists are supposed to provide culture consultation to multinational corporations to prevent them from corruption problems caused by attaching too much importance to the relationship with the government. Certainly, in the present academic research field all over the world, honest political construction in multinational corporations from the perspective of business anthropology is still a brand new topic.

\section{Definition and Development Phase of Business Anthropology}

Anthropology is an interdiscipline across natural and social science, namely, a social science focusing on human beings and their culture. Since anthropologists belong to different schools, they analyze and divide their discipline structures differently. It is acknowledged that the traditional four branches are physical anthropology, cultural anthropology, archaeological anthropology, and linguistic anthropology. Generally speaking, anthropology is roughly divided into a broad sense and narrow sense. Anthropology in a narrow sense is also called physical anthropology, which mainly refers to the study of the laws of development of human constitution and figures. Anthropology in a broad sense includes almost every aspect of human societal development. It covers the study of human social life, namely, the technology, economy, social structure, political laws, customs and habits, and transaction behaviors created by humans and inherited from the society. Anthropology in a broad sense can be divided into cultural anthropology or social anthropology, management anthropology, economic anthropology, educational anthropology, urban anthropology, environmental anthropology, and so on (Lan, 2011).

Anthropology was recognized in the academic field and turned into a rapidly developed discipline in the twentieth century in the west because of its unique research methods. At the end of the twentieth century, the considerable impacts of industrial and technological civilization blocked the development of anthropology. However in recent years, anthropology, especially applied anthropology which majors in administration and solving of practical problems, has undergone rapid development. In fact, applied anthropology is a general term that includes all the fields applying 
the methods of anthropology to study administration and solve practical problems. For example, when we study and solve educational problems by applying the methods of anthropology, we call these studies educational anthropology (Zhao, 2008). Similarly, when anthropology is applied to study, explore, and solve problems during the process of business management, we call it business anthropology.

In recent years, in the vast sea of anthropology research categories, business anthropology has been attracting the attention of many anthropologists and researchers with its unique charm, and has been developing rapidly in the west, particularly in the United States. Business anthropology is a new branch of applied anthropology. In the traditional four branches, it should be included in cultural anthropology, which has a close connection with economy and management. In China, the Chinese scholars are gradually realizing the importance of business anthropology. With the deepening of economic globalization, business anthropology has a broad scope for development.

Business anthropology is applying the theories and methods of anthropology to solve problems concerning business and industrial activity. It is generally acknowledged that business anthropology can be traced back to the nineteenth century European colonialism. The term "business anthropology" had not been used until the 1980s. Early in the nineteenth century, anthropologists were employed by the British East India Company to study India for the company's benefit. However, in the academic field of anthropology, it is widely believed that the recognized event symbolizing the formation of business anthropology was the Hawthorne Project in 1924 (Jordan, 2010).

There are four periods in the development of business anthropology. The first period was the Hawthorne Project in 1924. In the 1920s and 1930s, American anthropologists W. Lloyd Warner and Elton Mayo jointly participated in a study in which employees' behaviors were observed. The object of the study was the employees, and the purpose was the connection between interpersonal relationship and labor efficiency. The location of the project was a Chicago factory of the American Western Electric Company.

The second period was the in 1950s, after WWII. Anthropologist Marietta L. Baba set up a consulting company that used anthropological methods. Anthropologist Helen B. Schwartzman came up with the importance of cross-cultural communication. These studies were pioneers of business anthropology consultancy and were all meaningful attempts. However, it cannot be considered as a systematic period of the anthropologists' study of business anthropology (Bruce, 2006). 
The third period was in the 1960s and the 1970s. With the global expansion of the American military force, anthropologists were secretly employed by the government to engage in field work in different cultural regions, including Vietnam, Latin America, and so on. This action was regarded as violating professional ethics, so it was opposed by the anthropologists. Meanwhile, the government had seen the anthropologists' contribution to politics and so they started to hire more of them to conduct researches into the problems on their agenda. With this background, the Code of Professional Responsibility was established in anthropology (Baba, 2006): this bound the anthropologists, which led to small progress in the study of business anthropology during the next ten years (Holzberg, 1981).

The fourth period was in the 1980s. During this period, the American Anthropology Association agreed to the professional study of anthropology, so more anthropologists worked in business management consultancy. In 1987, America established the first committee to study organizational culture, management science and quarterly publications. During this period, business organizations became interested in the study of human beings, and the anthropologists' further studies benefited from the help and promotion by business organizations. In 1982, as Tom Peters and Robert $\mathrm{H}$. Waterman discovered that organizational culture was a factor in achieving excellence, the topic leapt to the top of the corporate agenda. Kennedy's (1988) study has made organizational culture one of the major topics in the recent 30 years (Tian, 2010).

Since the 1990s, the contribution of the anthropologists has been recognized by more and more enterprise managers, and it has become the backbone of business management research (Tian, 2013). Business anthropology in China is still in the initial stage. For the past few years, among the many scholars, the study of Tian Guang, of Chinese origin, has received much attention. His major contribution to business anthropology is applying anthropological theory and methods to studying cross-cultural marketing, anthropology and administrative education, and food culture and consumer behavior. At the same time, Tian Guang once mentioned that in multinational corporations, because of cultural differences, some enterprises attached too much importance to the relationship with government, and some even bribed government officials to seek excessive benefits. Anthropologists can provide culture consultations to multinational corporations to avoid losses (Qi, 2012). 


\section{Culture Conflicts Confronted by Multinational Corporations When Operating Overseas}

A multinational corporation is also known as an international firm, a multi-national enterprise, a cosmo-corporation, or supernational enterprise, and so on. At the beginning of the 1970s, The U.N. Economic and Social Council formed a joint investigation team to carry out a thorough investigation of all kinds of principles and definitions of multinational corporations. Multinational corporations have the following features: 1) they are usually dominated by a large company from a country with economic strength. Subsidiary corporations or branches are established in many countries by acquisitions of local enterprises or OFDI (outward foreign direct investment); 2) there is usually a highest decision center and a complete decision system. Although the subsidiary corporations or branches can make decisions according to their field of business and their characters, the highest decision-making rights belong to the highest decision center; 3) they engage in business activities with global strategies to maximize their profits by reasonable deployment of production in the world; 4) they usually embrace advantages including abundant economic and technological strength, rapid information delivery speed, fast multinational capital transferring, and strong international competitiveness; 5) large multinational corporations usually possess some degree of monopoly because of their advantages in competitiveness; and 6) they are equipped with enormous financial strength and extensive social resources. As a result, their means of bribing are multiple and less noticeable compared to small companies in China. Multinational commercial bribes cannot be detected, so are known in the industry as the "perfect bribe".

In recent years, with the approach of economic globalization, an increasing number of Chinese companies have been investing and operating abroad. At present, the behaviors of state-owned and private enterprises who manage their multinational businesses abroad show that the overseas investment from Chinese businessmen groups and relevant departments is not mature enough. Because of the differences in social systems, management concepts and styles, behavioral habits, and so on, contradictions and conflicts can occur in management, so the enterprises depend too much on their relationship with the government, which brings poor social habits formed in their own country to the host country. Enterprise culture is the value, belief, and way of action acknowledged and followed by all the employees (Zhang, 2014). In general, it can be divided into four levels: concept, system, material, and behavior. The core is the concept level including value, vision, spirit, mission, enterprise 
philosophy, management philosophy, business ideas, and so on; the system level covers all the systems and norms, especially the HR (human resource) system which is closely connected to the enterprise culture; the material level includes the office environment, internal publications, statues, bulletin boards, and any other external things that reflect the enterprise culture; and the behavior level covers high-level, middle-level, basic-level, and employees-reflecting-enterprise-culture management behaviors.

The core of enterprise culture is shared values. The conflict of values generally manifests as a broad scale and deep level of contradiction. Value determines the people's behavior with its strong objectivity. Different countries and nations have different value systems. Individuals can form unique values in the long-term life practices. It is therefore extremely urgent for the enterprises to enhance the study of culture and promote the awakening of enterprise culture. We should study and advocate the theory, concept, and code of conduct of enterprise culture by combination of theory and practice, to make all the employees and managers familiar with the connotation, function, and meaning of enterprise culture and the connotation of enterprise concept. We should enhance the theoretical level of the enterprise culture and promote the understanding of the concept of the enterprise culture (Zhong, 2014).

Human beings' inner power is embodied in their thoughts. Similarly, multinational corporations' management is accomplished by the managers' understanding of enterprise management. In a multinational corporation, people with various cultural deposits and ideologies co-exist with each other. As a result, the best way to reflect inner culture is the manner and method of management. Thus, it can be seen that cultural connotations behind enterprise management have a non-negligible influence on enterprises. In some cases, even the concentrated reflection of a kind of thought can have many unexpected consequences. The enterprise culture can even determine the strategic choice (Priem, 2001). Culture is presented in the form of a group, and exists in people's daily lives. It uses human beings' languages and behaviors as carriers, and is displayed through the employees' communication and the enterprises' development policy. If not handled properly, it can lead to culture conflicts.

However, culture conflicts also have positive influences. In enterprise management, culture conflicts are more like double-edged swords. Although the results of culture conflicts can block the goals of enterprise management, they can also have advantages. In the development of multinational corporations, culture conflicts can provide vigor and creative thoughts. This cross-cultural advantage cannot be matched by pure 
domestic enterprise management. Therefore, the culture conflicts existing in multinational corporations do not always have negative effects on the survival and development of the enterprises. The existence of any kind of culture can be an important factor for the success of an enterprise, and a key condition of bringing employees closer. The enterprises should stand in the shoes of the opposing enterprise managers and enterprises to consider the problems and arrange to make the employees from different cultural backgrounds feel respected and equal. Then, once they understand and respect each other, the stability of the staff and business is ensured.

Hence, as long as the decision-makers make proper use of the double-effects of culture conflicts, take appropriate actions in enterprise management, and utilize the differences between cultures, enterprise development will unexpectedly get promoted (Kang, 2015).

The aim of an enterprise is to seek profits. To get large orders, multinational enterprises can use commercial bribery. To some extent, the major reason for domestic companies to bribe in the trade with foreign companies is the multinational commercial bribe phenomenon. Similarly, Chinese companies are facing extremely fierce market competition abroad. Especially in the present stage, fields such as infrastructure construction and mineral products still take the main share of Chinese overseas investments. However, these fields are just the "high-risk" industries where it is easy to breed commercial bribery. Multinational corporations engage in fierce competition when struggling for access rights to infrastructure construction and energy development projects in some emerging developing countries. To some extent, this provides a platform for the frequent occurrence of overseas commercial bribery. It is worth mentioning that as China is putting more efforts into overseas investment, the Chinese companies' overseas commercial bribery criminal events have also shown an upward trend. Faced with this kind of situation, the Chinese Ministry of Justice is supposed to plan ahead, kill overseas commercial bribery in the cradle, and learn lessons from developed Western countries about dealing with overseas commercial bribery to allow for a smooth Chinese economic development "going out" strategy (Lu, 2015).

\section{Multinational Corporations Facilitate Culture Consultations and Reinforce Incorruptible Construction Policies}

On 22nd June, 2008, the Central Committee of the CPC issued the Working Plan for Establishing and Perfecting Punishment and Prevention of Corruption System from 2008 to 2012, in which it is clearly stated that 
they 'strictly prohibit Chinese enterprises' commercial bribery behaviours abroad and investigate and punish overseas enterprises' commercial bribery behaviours in China." The 2012 executive meeting of the State Council assigned a reform task to "study and carry out individual overseas direct investment pilot projects and explore and establish specified and convenient direct investment channels" and passed the resolution to establish a comprehensive experimental area for financial reform in Wenzhou. This shows that the Chinese government actively encourages Chinese citizens to invest overseas. While Chinese companies are conducting transnational commercial activities, Chinese law enforcement is confronting commercial bribery issues in multinational enterprises, which is a severe challenge in our country. Accordingly, I propose the following countermeasures to provide culture consultations to multinational enterprises:

\section{Establishing Construction Institutions of Enterprise Culture}

Only if the culture construction in multinational corporations forms an institutionalized, scientific, and controlled mechanism can they have a place in the global market. Multinational enterprises should establish an enterprise culture construction institution and be equipped with chief anthropologists to study and construct cross-culture enterprise culture. They are responsible for compacting the enterprise culture concept, propagandizing the enterprise culture, and enhancing employee awareness of. Meanwhile, they are supposed to establish an excellent enterprise culture and action recognition system, positively create an enterprise culture atmosphere, and promote the scientific development of enterprise culture. Excellent enterprise culture and an action recognition system are the premises and foundations of excellent enterprises. They make clear the profound meaning of enterprise culture and strengthen the enterprise strategy. They create a high-quality enterprise image and a favorable human environment. Thus, multinational enterprises should construct cross-culture enterprise culture that matches their own enterprise culture to increase the employees' capability, enhance the enterprises' cohesion, eliminate the disadvantages of the old culture, and establish and develop new enterprise cultures.

\section{Analyzing Cultural Differences within Enterprises}

Cultural conflicts in multinational corporations have become more and more prominent owing to the increasing deepening of international exchanges and expanding international trade. Therefore, further study of 
intercultural conflicts can no longer be ignored (Shi, 2015). The American anthropologist Edward Hall divides culture into three levels: formal system, informal system, and technology system. Culture conflicts have diversity and limitations. Cross-culture multinational enterprises should master the culture conflicts within the enterprises. For multinational enterprises, conflicts in the formal system refer to the conflicts of values in enterprise commercial practices, due to the various national and cultural backgrounds. Conflicts in informal systems mainly refer to the conflicts in the ways of employee actions, customs, and habits, while conflicts in technology system are mainly the conflicts in technology rules. When multinational enterprises construct an enterprise culture, then only by a detailed analysis of the several cultures within the enterprises, comparing and analyzing the influence of culture on the management practices, and scientifically mastering the management mechanisms in different countries, can they properly solve the culture conflicts (Chen, 2009). For seeking common ground while putting aside differences, there is a need to establish a localization business strategy.

\section{Carrying on Cultural Choices Scientifically}

When multinational corporations allow cultural choices, they are not only supposed to respect the cultures at the investment locations, but solve the culture conflicts properly instead of blindly catering to them. Therefore, multinational enterprises should grasp the regularity of cultural integrity and take corresponding measures to seek common ground while reserving differences, reducing culture conflicts, and promoting cultural integrity in cross-culture enterprises. They should pay attention to choosing those cultural elements that tally with the enterprise features and absorb cultures that are beneficial to enterprise development. It is therefore extremely important to understand the religion and national cultural background of the host country, respect their mainstream values, and even invite culture experts to do some training on the cultural customs of the host country. Cultural choice is an iterative process. When culture conflicts occur among enterprise employees, the enterprise manager should make a further choice on the basis of cross-culture communication to form the overall culture, consisting of production management, technology, products, organization, and management, with the enterprise's own characteristics (Chen, 2009). 


\section{Conclusion}

On the whole, the study of business anthropology is an interdisciplinary cross-over study combining anthropology, management, and economics. Many business anthropologists not only work in the academic research field (universities or research institutes), but also work in large multinational corporations, consultation institutions, design companies, and other organizations. Business anthropology has by now passed the embryonic period, and is growing deeply. However, in China, the study of business anthropology still awaits further development. Many systems of theories still need to be improved, and the study of honest political construction is still rare. The participation of aspiring young men and the studies carried out by relevant scholars are still needed to help the Chinese academic subjects.

\section{References}

Baba, M. (2006). 'Anthropology and Business.' In H. James Birx (Ed.) Encyclopedia of Anthropology (pp. 83-117). Thousand Oaks, CA: Sage Publications.

Bruce,K.. (2006). 'Henry S. Dennison, Elton Mayo, and human relations historiography.' Management \& Organizational History, 1(2):177-99.

Chen Yanhong. (2009). 'Difficulties and coping strategies in enterprise culture construction with in multinational management enterprises.' Market Modernization,(1):311.

Holzberg. C.\& Giovannini, M. (1981). 'Anthropology and Industry: Reappraisal and New Directions.' Annual Review Of Anthropology. (10): 317-60.

Jordan A T.(2010). 'The importance of business anthropology: its unique contributions.' International Journal of Business Anthropology, $1(1): 15-25$.

Kang Xubo. (2015). 'Research on Multinational Company Performance Management of Cultural Conflict Problem.' Northern Economy And Trade, (1):143.

Lan Xuehua ,Tian Guang.(2011). 'Anthropology applied in commercial education and the rapid rise of industrial and commercial anthropology ' China management information,(4):70-5.

Lu Jinyong,Zou He,Cheng Jian. (2015). 'A Study on Multinational Corporation Corruption in China.' Contemporary Economic Management, (5):17. 
Oi Xioguang, Wang Xiaona, Liu Zhenyu .(2012). 'Discourse and Development of Management and Anthropology: the rise of industrial and commercial anthropology.' Dalian Maritime University Journal, (3):49.

Priem, R. L\& Butler, J. E. (2001). 'Is the Resource-Based View a Useful Perspective for Strategic Management Research.' Academy of Management Review, 26(1):22-40.

Shi Xiumei, Luan Hua. (2013). 'Research on Investment and Cross-cultural Conflicts in U.S. Multinational Companies in China.' Jiangsu Commercial Forum,(3):42.

Tian R.G. (2010). 'The unique contributions and the unique methodologies: a concise overview of the applications of business anthropology.' International Journal of Business Anthropology, $1(2): 70-88$.

Tian Guang, Zhou Daming.(2013). 'China needs to Business Anthropology.' MinZu Tribune,(6):7.

Zhang Yaohua. (2014).Multinational enterprise cultural conflict reason and deal with. China Market,(4):97.

Zhao Ziming, Chen Gang. (2008).The Anthropology. BeiJing: China Renmin University Press.

Zhong Jie. (2014). 'The Analysis Of Multinational enterprises cultural conflict and integration.' CO-Operative Economy and Science, (12): 125 